\title{
58. SEISMIC PROPERTIES OF VOLCANIC ROCKS FROM HESS RISE ${ }^{1}$
}

\author{
N. I. Christensen, R. H. Wilkens, S. M. Lundquist, and J. P. Schultz, Department of Geological Sciences and \\ Graduate Program in Geophysics, University of Washington, Seattle, Washington
}

\section{INTRODUCTION}

Hess Rise, a major structural feature in the northern Pacific, is one of several oceanic plateaus which apparently possess anomalous seismic structures (Sutton et al., 1971). Hence, Laboratory measurements of compressional- and shear-wave velocities in rocks from oceanic plateau regions are of considerable interest. Several questions come to mind: (1) Are compressionalwave velocities of volcanic rocks from oceanic plateaus similar to basalts of equivalent age from normal oceanic crust? (2) Do velocity-density relations for plateau rocks fit the well-established trends for Layer 2 basalts? (3) How do Poisson's ratios, determined from compressional- and shear-wave velocities, of oceanic plateau rocks compare with those of normal sea-floor basalts?

To answer these questions, we have selected for velocity measurements five volcanic samples from different depths (Fig. 1) from Hole 465A, on southern Hess Rise. It is particularly significant that all the rocks are vesicular and have been highly altered, which significantly affects their elastic properties.

\section{SAMPLE DESCRIPTIONS, EXPERIMENTAL PROCEDURE, AND DATA}

Four of the five samples are from the lower volcanic units and one is from the upper volcanic breccia (Fig. 1). One third of the breccia (465A-41-1) consists of volcanic clasts $5 \mathrm{~mm}$ in diameter in a carbonate matrix. The clasts range from semi-angular to rounded, depending on the degree of alteration to carbonate along the grain boundaries. The remainder of the sample consists of a five-grained volcanic rock and may compose a larger clast in the breccia.

The remaining four samples are highly altered, finegrained, vesicular volcanic rocks. They are porphyritic, with plagioclase phenocrysts in a glassy matrix, and they contain abundant plagioclase microlites. The glass has been altered to smectite. Vesicles range in size from 0.5 to $1 \mathrm{~mm}$ and are often filled with carbonate, as are many small veins and fractures. Some flow structure is apparent in one sample (465A-42-1), where the vesicles are elongated parallel to the trachytic plagioclase microlites. No mafic minerals are present in any of the samples, and the opaque minerals are unaltered.

Compressional-wave velocities have been measured in all five samples (Table 1), and shear-wave velocities in three (Table 2), using the pulse-transmission technique

\footnotetext{
${ }^{1}$ Initial Reports of the Deep Sea Drilling Project, Volume 62.
}

described in detail by Birch (1960). All velocities were measured at room temperature, using water-saturated samples. The samples were jacketed with copper foil, and 100-mesh screens were placed between the cores and copper jackets to provide space for water to drain from grain-boundary cracks as confining pressure was increased. Thus, pore pressure was kept much lower than confining pressure. The importance of using this technique in measuring velocities in oceanic rocks is discussed by Christensen and Salisbury (1975). Bulk densities (Table 1) were calculated from the weights and dimensions of the water-saturated samples.

In addition to shear-wave velocities $\left(V_{s}\right)$, the ratios of compressional- to shear-wave velocities $\left(V_{\mathrm{p}} / V_{s}\right)$, Poisson's ratios $(\sigma)$, bulk moduli $(K)$, shear moduli $(\mu)$, Lamé's constants $(\lambda)$, and Young's moduli $(E)$ are given in Table 2 at various pressures. The elastic constants were calculated from the velocities and densities, following the equations of Birch (1961).

\section{DISCUSSION}

Figure 2 shows compressional- and shear-wave velocities at $0.5 \mathrm{kbar}$ versus wet-bulk density for the data in Tables 1 and 2. Included in this figure are data points and non-linear regression curves presented by Christensen and Salisbury (1975) for DSDP basalts. It is apparent that while the measured velocities for our samples generally agree with the basalt trend, they are significantly lower than those of most samples studied. Of the Pacific Ocean basin samples used in the original velocity-density correlation, only four exhibited compressional-wave velocities less than $4.3 \mathrm{~km} / \mathrm{s}$ (Christensen, 1973; Christensen and Salisbury, 1973).

The reasons for the low seismic velocities of our samples appear to be the pervasive alteration of the primary minerals and the vesicularity of the rocks. Although calcite replacement of plagioclase should not seriously reduce seismic velocities, the alteration of the glassy matrix to smectite should have a significant effect. Porosity-velocity relationships have been examined previously for Atlantic Ocean basin basalts, and a good correlation was observed between a decrease in seismic velocity and an increase in porosity (Christensen et al., 1980). Based on wet and dry weights of our samples, we estimate that their porosities range between 10 and $20 \%$.

It is interesting to note that whereas other Pacific basin DSDP basalt samples generally exhibit relatively higher seismic velocities, seismic velocities recently measured for basalt samples from island-arc and backarc-basin areas (Christensen, Blair, et al., in press; 


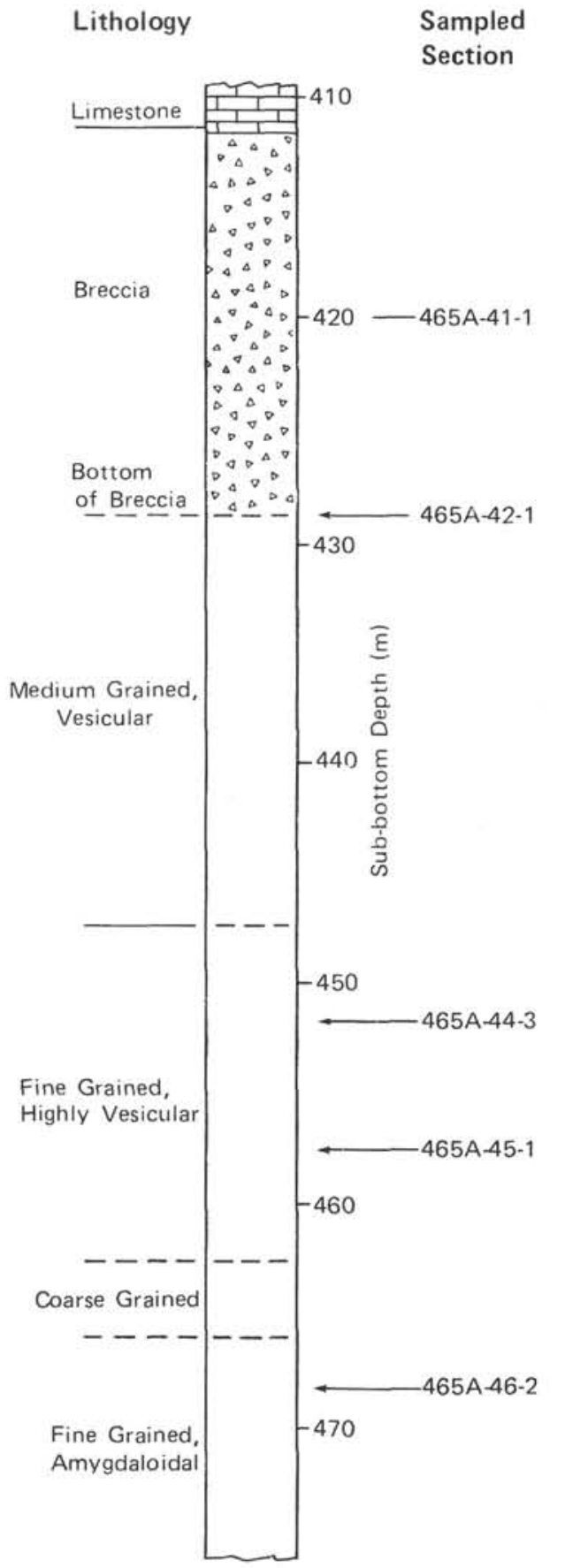

Figure 1. Sample locations and basement lithology of Hole 465A.

Table 1. Compressional-wave velocities $\left(V_{\mathrm{p}}\right)$.

\begin{tabular}{|c|c|c|c|c|c|c|c|}
\hline \multirow{2}{*}{$\begin{array}{c}\text { Sample } \\
\text { (interval in } \mathrm{cm} \text { ) }\end{array}$} & \multirow{2}{*}{$\begin{array}{l}\text { Porosity } \\
(\%)\end{array}$} & \multirow{2}{*}{$\begin{array}{l}\text { Wet-Bulk } \\
\text { Density } \\
\left(\mathrm{g} / \mathrm{cm}^{3}\right)\end{array}$} & \multicolumn{5}{|c|}{$\begin{array}{l}\text { Velocity }(\mathrm{km} / \mathrm{s}) \\
\text { at Varying Pressures (kbar) }\end{array}$} \\
\hline & & & 0.2 & 0.4 & 0.6 & 0.8 & 1.0 \\
\hline $465 \mathrm{~A}-41-1,90-95$ & 14.80 & 2.770 & 3.33 & 3.40 & 3.44 & 3.47 & 3.50 \\
\hline $465 \mathrm{~A}-42-1,134-139$ & 14.95 & 2.090 & 3.29 & 3.34 & 3.37 & 3.40 & 3.43 \\
\hline $465 \mathrm{~A}-44-3,138-143$ & 10.54 & 2.306 & 3.96 & 3.98 & 3.99 & 3.99 & 3.99 \\
\hline $465 \mathrm{~A}-45-1,76-81$ & 8.96 & 2.310 & 4.00 & 4.03 & 4.05 & 4.08 & 4.10 \\
\hline $465 A-46-2,55-60$ & 10.35 & 2.273 & 3.79 & 3.83 & 3.87 & 3.89 & 3.91 \\
\hline
\end{tabular}

Table 2. Elastic constants and shear-wave velocities $\left(V_{\mathrm{S}}\right)$.

\begin{tabular}{ccccccccc}
\hline $\begin{array}{c}\text { Sample } \\
\text { (interval in cm) }\end{array}$ & $\begin{array}{c}\text { Pressure } \\
(\mathrm{kbar})\end{array}$ & $\begin{array}{c}V_{\mathrm{s}} \\
(\mathrm{km} / \mathrm{s})\end{array}$ & $V_{\mathrm{p}} / V_{\mathrm{s}}$ & $\sigma$ & $\begin{array}{c}K \\
(\mathrm{Mbar})\end{array}$ & $\begin{array}{c}{ }^{\mu} \\
\text { (Mbar) }\end{array}$ & $\begin{array}{c}E \\
\text { (Mbar) }\end{array}$ & $\begin{array}{c}\lambda \\
\text { (Mbar) }\end{array}$ \\
\hline 465A-44-3, 138-143 & 0.20 & 2.01 & 1.97 & 0.33 & 0.24 & 0.09 & 0.25 & 0.18 \\
& 0.40 & 2.02 & 1.97 & 0.33 & 0.24 & 0.09 & 0.25 & 0.18 \\
& 0.60 & 2.02 & 1.98 & 0.33 & 0.24 & 0.09 & 0.25 & 0.18 \\
& 0.80 & 2.03 & 1.97 & 0.33 & 0.24 & 0.10 & 0.25 & 0.18 \\
& 1.00 & 2.03 & 1.97 & 0.33 & 0.24 & 0.10 & 0.25 & 0.18 \\
& 0.20 & 2.06 & 1.94 & 0.32 & 0.24 & 0.10 & 0.26 & 0.17 \\
& 0.40 & 2.08 & 1.94 & 0.32 & 0.24 & 0.10 & 0.26 & 0.18 \\
& 0.60 & 2.09 & 1.94 & 0.32 & 0.24 & 0.10 & 0.27 & 0.18 \\
& 0.80 & 2.09 & 1.95 & 0.32 & 0.25 & 0.10 & 0.27 & 0.18 \\
& 1.00 & 2.10 & 1.95 & 0.32 & 0.25 & 0.10 & 0.27 & 0.18 \\
& 0.20 & 1.86 & 2.04 & 0.34 & 0.22 & 0.08 & 0.21 & 0.17 \\
& 0.40 & 1.89 & 2.03 & 0.34 & 0.23 & 0.08 & 0.22 & 0.17 \\
& 0.60 & 1.91 & 2.03 & 0.34 & 0.23 & 0.08 & 0.22 & 0.17 \\
& 0.80 & 1.94 & 2.01 & 0.33 & 0.23 & 0.09 & 0.23 & 0.17 \\
& 1.00 & 1.96 & 1.99 & 0.33 & 0.23 & 0.09 & 0.23 & 0.17 \\
\hline
\end{tabular}

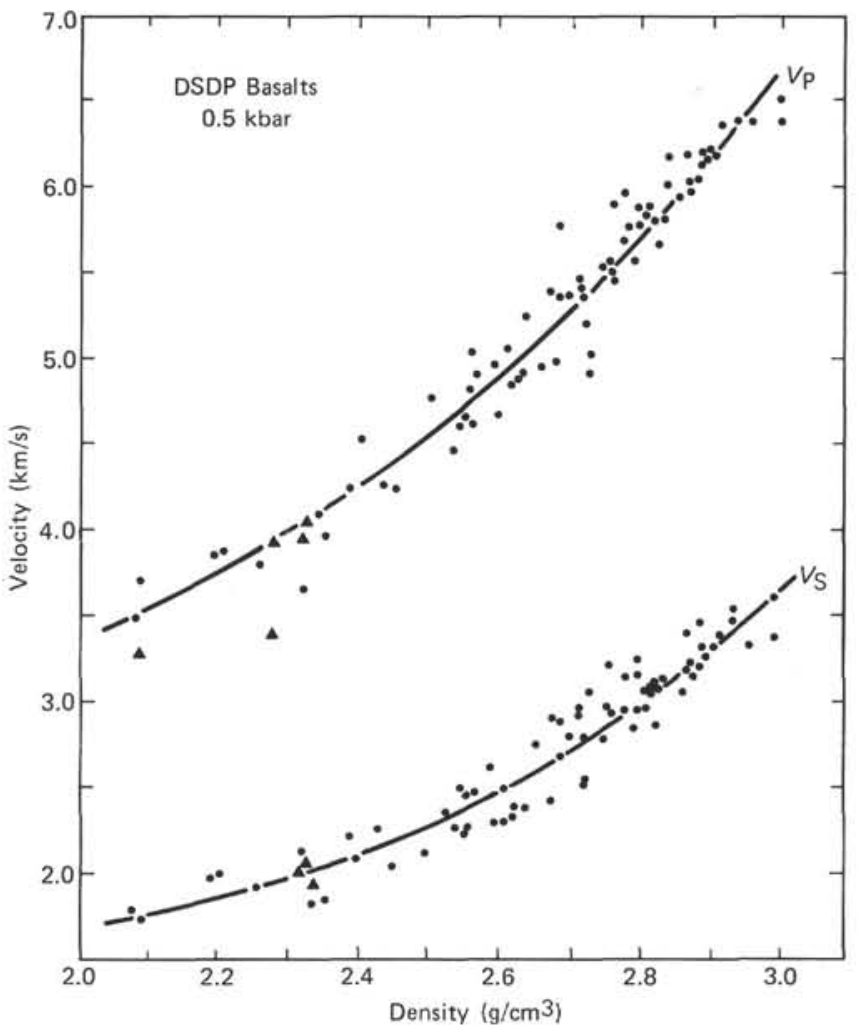

Figure 2. Compressional and shear-wave velocities at $0.5 \mathrm{kbar}$ versus wet-bulk density. Solid triangles represent data from this study; other data are from Christensen and Salisbury (1975).

Christensen, Wilkens, in press) are often in the same range as those of the Hess Rise samples, reported here. Furthermore, the values of Poisson's ratio reported in Table 2 are generally higher than the average for DSDP basalts (Christensen and Salisbury, 1975), but agree well with values reported from the island-arc and back-arcbasin sites.

It is unfortunate that there are no published seismicrefraction profiles of the Hess Rise. This precludes estimation of the depth to which these low-velocity rocks persist, beyond the 70 meters directly sampled by drilling. Future interpretation of seismic data in this region must take into account the fact that velocity contrasts at the sediment/basement interface may be sig- 
nificantly lower than those normally encountered in ocean basins.

\section{ACKNOWLEDGMENTS}

Financial support for this study was provided by Office of Naval Research Contract N-0014-75-C-0502. The manuscript was reviewed by R. I. Carlson and S. C. Blair.

\section{REFERENCES}

Birch, F., 1960. The velocity of compressional waves in rocks to 10 kilobars, 1. J. Geophys. Res., 65:1083-1102.

1961. The velocity of compressional waves in rocks to 10 kilobars, 2. J. Geophys. Res., 66:2199-2224.

Christensen, N. I., 1973. Compressional and shear wave velocities in basaltic rocks, Deep Sea Drilling Project, Leg 16. In van Andel, Tj. H., Heath, G. R., et al., Init. Repts. DSDP, 16: Washington (U.S. Govt. Printing Office), 647-649.

Christensen, N. I., Blair, S. C., Prior, R. C., et al., in press. Seismic velocities at elevated pressures of igneous rocks from the Mariana Trough and fore-arc region, Deep Sea Drilling Project Leg 60. In Hussong, D., Uyeda, S., et al., Init. Repts. DSDP, 60: Washington (U.S. Govt. Printing Office).
Christensen, N. I., Blair, S. C., Wilkens, R. H., et al., 1980. Compressional wave velocities, densities, and porosities of basalts from Holes 417A, 417D and 418A, Deep Sea Drilling Project Legs 51 through 53. In Donnelly, T., Francheteau, J., Bryan, W., Robinson, R., Flower, M., Salisbury, M., et al., Init. Repts. DSDP, 51, 52, 53, Pt. 1: Washington (U.S. Govt. Printing Office), 14671472 .

Christensen, N. I., and Salisbury, M. H., 1973. Velocities, elastic moduli and weathering-age relationships for Pacific layer 2 basalts. Earth Planet. Sci. Lett., 19:461-465.

1975. Structure and constitution of the lower oceanic crust. Rev. Geophys. Space Phys., 13:57-86.

Christensen, N. I., Wilkens, R. H., Blair, S. C., et al., in press. Seismic velocities, densities and elastic constants of volcanic breccias and basalt from Deep Sea Drilling Project Leg 59. In Kroenke, L. Scott, R., et al., Init. Repts. DSDP, 59: Washington (U.S. Govt. Printing Office).

Sutton, G. H., Maynard, G. H., and Hussong, D. M., 1971. Widespread occurrence of a high-velocity basalt layer in the Pacific crust found with repetitive sources and sonobuoys. In Heacock, J. G. (Ed.), The Structure and Physical Properties of the Earth's Crust: Geophys. Monogr. Ser., 14: Washington (Am. Geophys. Union), pp. 193-209. 